\title{
SEISMIC BASE ISOLATION IN STRENGTHENING AN EXISTING RETROFITTED MASONRY-REINFORCED CONCRETE BUILDING IN HUATING - CHINA
}

\author{
Okine Michael Nii Sarbah ${ }^{1}$, Zhao Jianchang ${ }^{2}$, Mashrah Waleed Ali Hamed ${ }^{3}$ \\ ${ }^{I}$ MSc. Structural Engineering Student. School of Civil Engineering, Lanzhou Jiaotong University, Lanzhou, China \\ ${ }^{2}$ Professors, School of Civil Engineering, Lanzhou Jiaotong University, Lanzhou, China \\ ${ }^{3}$ MSc. Structural Engineering Student. School of Civil Engineering, Lanzhou Jiaotong University, Lanzhou, China
}

\begin{abstract}
Seismic base isolation is a fast advancing technology in which the superstructure is isolated from the entire structure or from the substructure by means of rubber bearing isolators or frictional sliding isolators. The main aim of the base isolation technology is to isolate the structure from the harmful effects of the ground accelerations or earthquake excitations. In this paper, the procedure for the selection of the three ground motions is briefly explained and they are used in analyzing a masonry - reinforced concrete office building for the Internal Revenue Service in the Huating County of the Pingliang City in China. The structure is first analyzed with the PKPM software to ascertain the structural internal forces are within reasonable limits but because this software cannot be used to advance analysis in the area of base isolation, Sap 2000 is used to remodel the structure, analyze, then apply the seismic base isolation. This office building has been strengthened to be fortified against ultimate bearing capacity failure as it is an existing structure. The lead rubber bearing isolators, LRB 400, LRB 500 and LRB 600 are used to isolate the building model and results from the structural response are compared, first amongst the time histories and then between the enveloped time histories and the response spectrum. The floor joint accelerations are observed to be reduced and the joint velocities as well, whereas the floor joint displacements are increased. The response spectrum alone is seen to not be an enough ground acceleration parameter in a seismic analysis and design of this model; as such it is recommended to include time history analysis. The maximum percentage decrease in acceleration and velocity can be seen occurring in the response spectrum, namely, $85.82 \%$ and $59.76 \%$, respectively. The maximum percentage increase in the displacement is also evident in the response spectrum, $57.59 \%$. In the time histories, the maximum is seen in Ec County Y-direction for the acceleration reduction at a value of 60.57\%; Delta artif records a maximum velocity reduction of $28.42 \%$ in the $Y$-direction and finally, the Delta artif $X$-direction also records a maximum displacement increment, at a value of $26.36 \%$.
\end{abstract}

Key Words: Seismic base isolation, Retrofitting, Strengthening, Masonry - reinforced concrete building, Time history analysis, Response spectrum analysis, Sap2000, PKPM software, Lead rubber isolator (LRB)

\section{INTRODUCTION}

Seismic base isolation is an exceptional technique in which the superstructure of a structure is isolated or separated from the foundation or separated from direct contact with the ground to minimize the harmful seismic effects that the seismic ground motions induce into the structure. Engineering practice and research have proven that, for high-rise and super high-rise buildings, the greater the elevation of the structure, the more the highest or top floor's displacements $[1,2,3]$. These days, the concept of seismic design is not only applied on high-rise or super high-rise buildings but also conducted on relatively important or special buildings, though they may be low-rise [4, 5]. In that same respect, strengthening an existing structure to preserve its cultural value and historical significance also counts as important within the context of the subject matter. There are many methods that can be used to dissipate energy from a building structure but the two widely used are: passive energy dissipation and seismic base isolation.

In China, the extensively used seismic base isolation devices are put into three categories, namely the: natural rubber bearings, NRB, high rubber bearings, HRB and lead rubber bearings, LRB [6]. With respect to the situation abroad, there are the cross linear device or steel bracings, the sliding plate and the friction pendulum isolation devices which can be further divided into single, double and triple friction pendulum devices [7]. The main difference between the energy dissipation devices and the seismic base isolators are that: seismic isolators comprise rubber bearings whereas the energy dissipaters comprise a variety of devices. For instance, diagonal bracing, shear walls, beam supporting structural components, velocity-related energy dissipation devices and displacement-related energy dissipation devices [8]. In the provision and placement of the base isolators, the entire structure is divided into three parts, namely: the superstructure, the base isolation layer and the foundation.

It is impossible to completely separate the superstructure from the substructure as in most buildings, for they were constructed in-situ and as a monolithic structure, especially 
with respect to their connection joints. The more cost effective way is to identify the higher displacement contributing ground columns, support those portions of the building from below the ground columns, cut and then eliminate a portion of the column in direct contact with the ground base. At this point the base isolators are installed. The base isolators could be installed on the ground beams for a completely masonry structure as the newly cast ground beams will support the masonry structure $[9,10]$, however the deflection would be enormous so this method should be implemented with mechanics of structure and the concept of seismic design in mind. Tampering or eliminating portions of the building, and then carrying out this procedure demands a great deal of skill and as such this method of applying seismic isolators on retrofitted structures is not an easy to carry out procedure. A great deal of expertise is needed in the retrofits and the installation of the bearing pads.

\section{MODEL DEVELOPMENT}

\subsection{The Structural Model}

A live project from a 4-storey stregnthening and rehabilitation project from the Internal Revenue Service Office building in the Huating county, of the Pingliang city is further improved in its structural safety by carrying out seismic base isolation on the structure. Pingliang city is located in the eastern part of the Gansu province, between the Guyuan city in the Ningxia province and Qingyang city in the Gansu Province. There have been many frequent earthquakes in the region of Huating with small intensities, mostly not exceeding 5.0 in magnitude but there have also been rarely occurring earthquakes of magnitude 6.5 recorded in the area in 1306, a 5.0 magnitude in 1921 and a magnitude of 5.0 in 1989 [9]. The seismic precautionary intensity for Pingliang is a level 7 and that for Huating County is a level 8 . The basic earthquake acceleration of the land is of value $0.20 \mathrm{~g}$, therefore a maximum design acceleration of $0.16 \mathrm{~g}$ is used. The design earthquake is of group 3 , the building seismic design is of category 3 or $\mathrm{C}$ class and the land is of category II. The site classification is of the second group and the characteristic period is $0.45 \mathrm{~s}$. The office is a $43.2 \mathrm{~m} \mathrm{X} 17.4 \mathrm{~m}$ building, and of height $14.5 \mathrm{~m}$, as shown in figures 1 and 2 .

The building structure is a third category, in terms of the importance precautionary category (binglei) and not that of the first (jialei) or the second (yilei), so there is no need to increase the seismic precautionary intensity by a level; on the other hand, the importance precautionary level for the third category can be reduced by a level or a level and a half when dealing with anti-seismic controlling measures for the building, as is shown in section 3.3.2 of the GB50011 code [5]. Apart from the first floor plan, the other plans are quite similar but the cross sections of the structural elements differ through the plans. Fig -3 and 4 show the floor plans.

\subsection{Design of the Model}

The structural analysis and design software, PKPM (in Chinese) is used to design the building structure but it cannot be used to advance analysis in the aspect of base isolation. In that regard, the Structural Analysis Program, Sap2000 is used to remodel the structure once more with the same structural elements used in the PKPM software, reanalyze the un-isolated structure; then analyze the isolated structure with the isolators. The cross sections for the structural model are made in accordance with the directives stipulated within the GB 50010 [4].

The PKPM or SAP2000 softwares are employed to:

A). Assess the acceptable structural member sizing, floor or story displacements and the deformations that the building structure undergoes.

B). Detect the behavioral pattern and effectively carry out the design of structural retrofitting or strengthening of the building structure.

C). Carry out the seismic analysis on the structure with the placement of the base isolators.

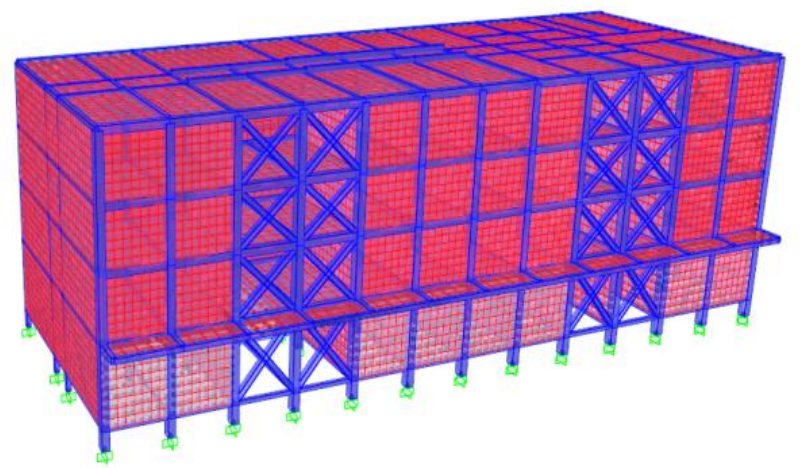

Fig -1: Sap2000 structural model

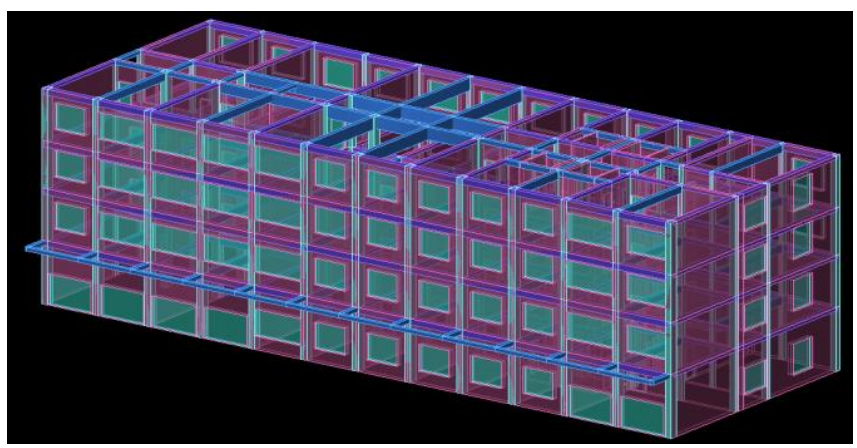

Fig -2: PKPM structural model

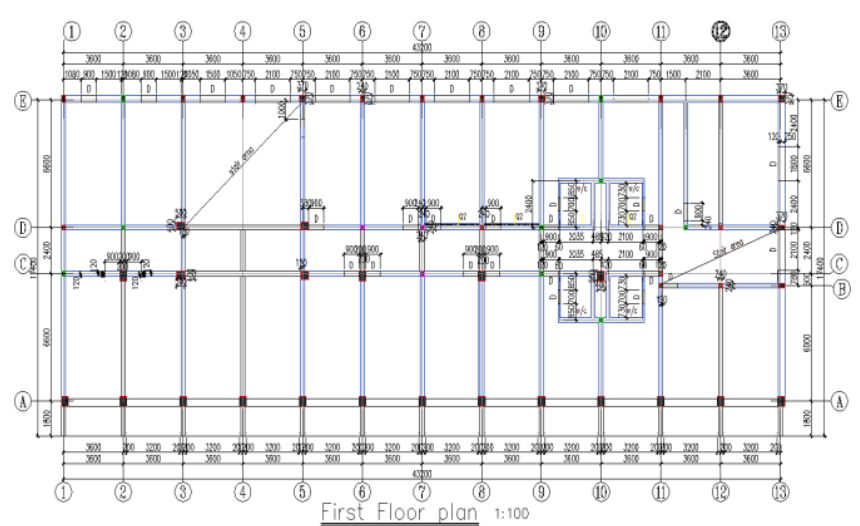

Fig -3: Typical 1st floor plan 


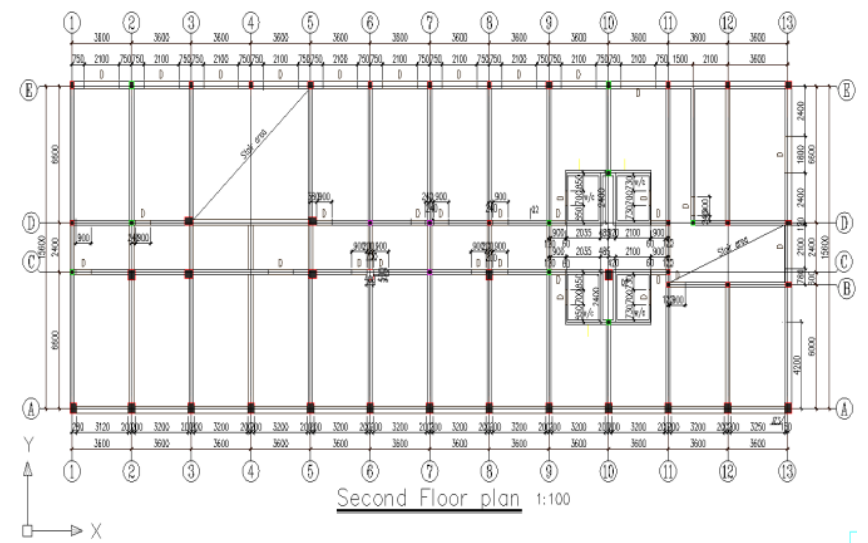

Fig -4: Typical 2nd to 4th floor plans

\section{SEISMIC DESIGN REQUIREMENTS}

\subsection{Provisions from the Chinese Code}

The chapter 12 and appendix L of the GB 50011-2010, together with other similar codes illustrate the base isolation methods to be carried out when designing. The section 5.1.2-1 for the GB 50011-2010 stipulates that, structures with elevation above ground level not exceeding 40 meters, with the major deformation being that of shear deformation; having the mass and stiffness through the elevation of the structure being relatively uniform, then simplification of the structural floors can be idealized into concentrated masses at the different floors, so that the structure could be analyzed with the base shear method and not the modal decomposition response spectrum method. This method is just for simplification and as such it is not a must to adhere to it.

\subsection{Selection of Ground Motions}

The ground motions were selected with the help of the online-based data source available in the PEER NGA-West2 website [12]. The response spectrum for the Huating County is constructed with the provisions from the code [5]. Highlights of the equations for constructing the response spectrum are shown in the section 5.1.5 of the code [5], and are used in forming the graph in figure 5 and 6.

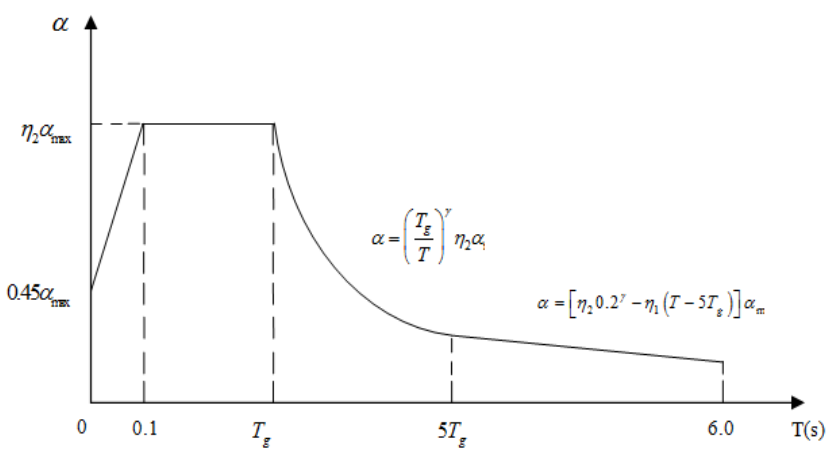

Fig -5: Code Response Spectrum

The response spectrum for Huating is thus constructed with the stipulated provisions from the building seismic parameters with the maximum peak ground acceleration being $0.16 \mathrm{~g}$ for a level $8,0.2 \mathrm{~g}$ earthquake site.

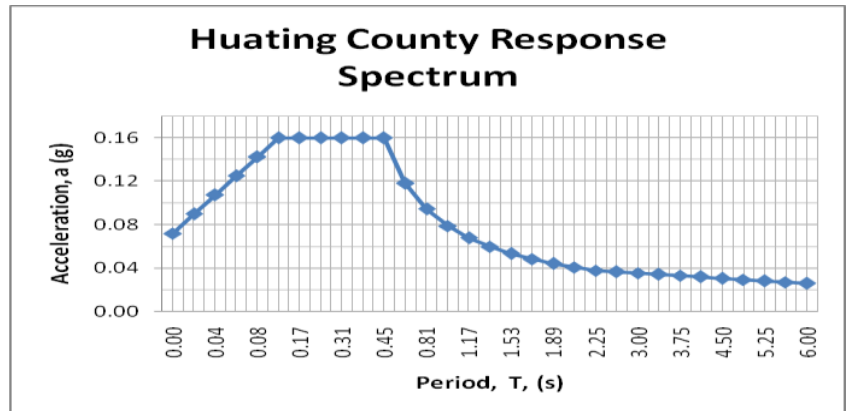

Fig -6: Huating County response spectrum

The response spectrum is entered into the PEER site together with other related building and site class information. A list of related earthquake ground motions are then generated with their properties outline in a tabular form. These ground motions are further analyzed and the artificial ground motion is generated by the help of the Seismosoft software products [13] from the original Delta ground motion, thus termed Delta Artif. Figures 7 through 9 [13] show the horizontal components of the accelerations in $\mathrm{cm} / \mathrm{s}^{2}$ for the selected time histories for this project and the table 1 [12] shows the properties for these ground motions.

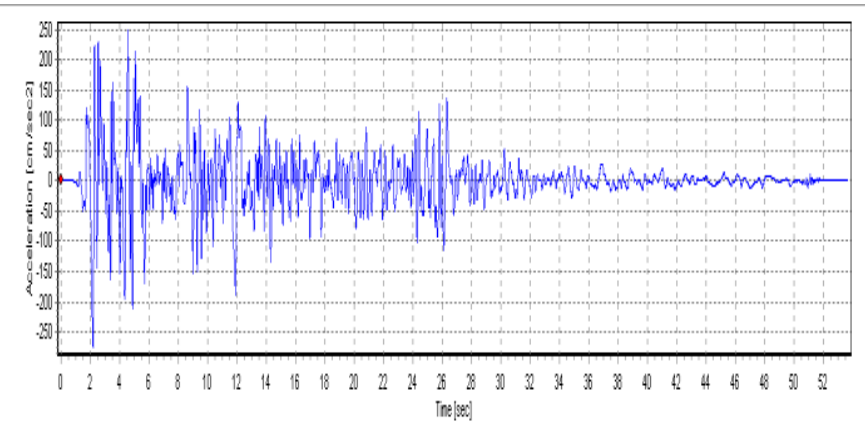

Fig -7: El Centro ground motion

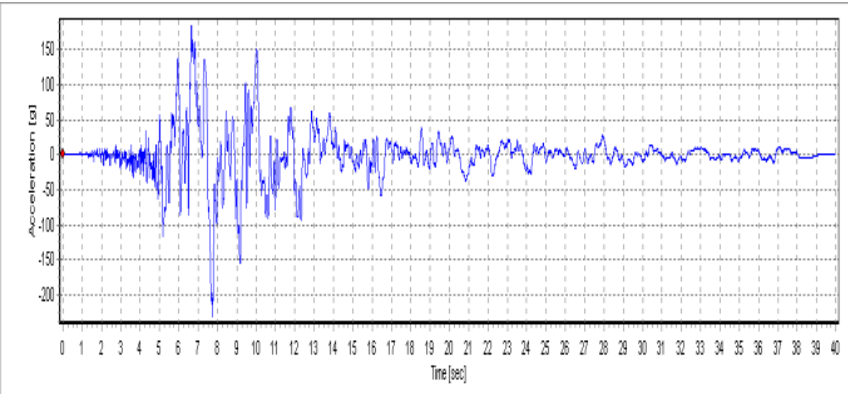

Fig -8: Ec County ground motion

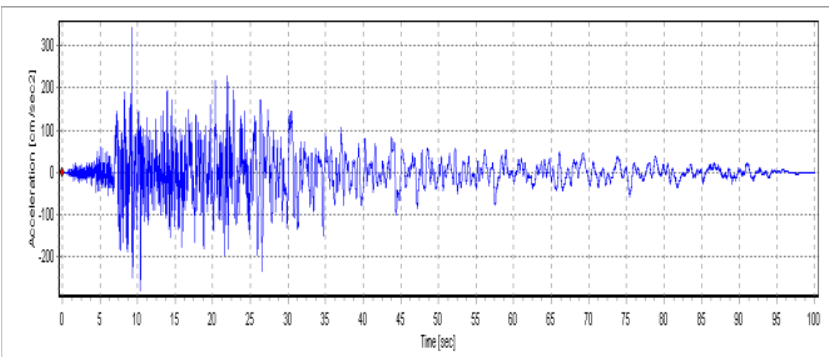

Fig -9: Delta Artif ground motion 
Table -1: Selected ground motions with their properties

\begin{tabular}{|l|l|l|l|}
\hline Parameter & $\begin{array}{l}\text { Ground } \\
\text { Motion 1 }\end{array}$ & $\begin{array}{l}\text { Ground } \\
\text { Motion 2 }\end{array}$ & $\begin{array}{l}\text { Ground Motion } \\
3\end{array}$ \\
\hline $\begin{array}{l}\text { Earthquak } \\
\text { e name }\end{array}$ & $\begin{array}{l}\text { Imperial } \\
\text { Valley-06 }\end{array}$ & $\begin{array}{l}\text { Imperial } \\
\text { Valley-02 }\end{array}$ & Artificial \\
\hline $\begin{array}{l}\text { Station } \\
\text { name }\end{array}$ & $\begin{array}{l}\text { Ec County } \\
\text { Center Ff }\end{array}$ & $\begin{array}{l}\text { El Centro } \\
\text { Array \#9 }\end{array}$ & Delta Artif \\
\hline $\begin{array}{l}\text { Compone } \\
\text { nt }\end{array}$ & $\begin{array}{l}\text { Impvall.H_ } \\
\text { H-Ecc092 }\end{array}$ & $\begin{array}{l}\text { Impvall.I_ } \\
\text { I-Elc180 }\end{array}$ & $\begin{array}{l}\text { IMPVALL.H_ } \\
\text { H- } \\
\text { DLT352.AT2 }\end{array}$ \\
\hline $\begin{array}{l}\text { North- } \\
\text { South (N- }\end{array}$ & $\begin{array}{l}\text { North-South } \\
\text { (N-S) }\end{array}$ \\
\hline $\begin{array}{l}\text { Magnitud } \\
\text { e }\end{array}$ & $\begin{array}{l}\text { East-West } \\
\text { E-W) }\end{array}$ & S) & 6.53 \\
\hline $\begin{array}{l}\text { Mechanis } \\
\text { m }\end{array}$ & Strike slip & Strike slip & Strike slip \\
\hline Year & 1979 & 1940 & 1979 \\
\hline PGA cm/s & 230.9518 & 275.4604 & 343.0551 \\
\hline $\begin{array}{l}\text { Mean } \\
\text { Square }\end{array}$ & 0.1042 & 0.1440 & 0.0674 \\
\hline $\begin{array}{l}\text { Arias } \\
\text { Intensity }\end{array}$ & 0.8 & 1.6 & 3.3 \\
\hline
\end{tabular}

\subsection{Base Isolators}

There are many types of isolators in use today, in a fast, advancing world of technology. The main types are the rubber bearing isolators and the friction or sliding isolators. Both have similar principles of action that is to decouple the superstructure from earthquake tremors that hit the structure. Within the first group of isolators, there are the high damping rubber isolators (HDRB), the natural rubber isolators (NRB) and the lead rubber bearing isolators (LRB). The NRB comprises thin films of rubber interlaced with metallic thin plates. The HDRB are highly damped NRB isolators and the LRB are NRB isolators with a central lead core providing added support for the bearing capacity of the building and being able to reduce the horizontal displacements of the building. The LRB usually exhibits a bilinear hysteretic behavior when assessed on the force deformation curve. The LRBs are used primarily for this project. The section 12.2.2 of the code [5] provides a simplified calculation model for seismic base isolators, as shown in figure 10 .

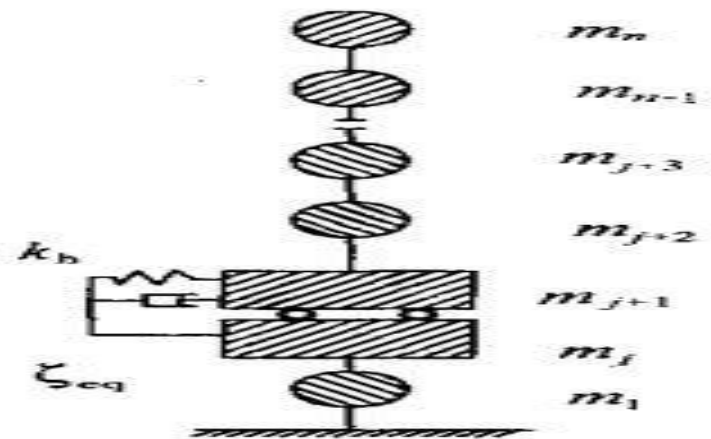

Fig -10: Calculation model for isolated structure
The section 7.2 of the code [14] stipulates that the 1st and 2nd shape factor coefficients $\left(\mathrm{S}_{1}, \mathrm{~S}_{2}\right)$ should conform to the set standards. For the purpose of ensuring that the base isolator satisfies the criterion under the vertical bearing capacity, $S_{1} \geq 15$. Under the effect of earthquake action, the base isolators can undergo very large horizontal deformations; as such the code stipulates that under high compressive stresses, the base isolator should not in any way, lose its stability. As a controlling measure, the S2 coefficient is needed to be within the range of, $S_{2} \geq 5$. There are 3 different types of LRBs chosen for this project; with their properties highlighted in table 2 . It can be seen that, all the isolators satisfy the preliminary checks for the shape factor coefficients, $S_{1}$ and $S_{2}$. The GZY prefix is another prefix used in lieu of the LRB, by the manufacturers and also a widely used prefix in China, as such, GZY is used interchangeably in this paper to mean one and the same thing. The 3 isolators are chosen from one of the Guangdong Limited manufacturing companies' for isolation technology [15]. The idealized hysteresis curve for the LRB is then given in figure 11 [16]

Table -2: Selected isolator and their properties

\begin{tabular}{|l|l|l|l|l|l|l|}
\hline $\begin{array}{l}\text { mod } \\
\text { el } \\
\text { num } \\
\text { ber }\end{array}$ & $\begin{array}{l}\text { Desi } \\
\text { gn } \\
\text { Ulti } \\
\text { mate } \\
\text { Bear } \\
\text { ing } \\
\text { Cap } \\
\text { acity }\end{array}$ & $\begin{array}{l}\text { Design } \\
\text { Displac } \\
\text { ement }\end{array}$ & $\begin{array}{l}\text { Rubb } \\
\text { er } \\
\text { Total } \\
\text { Thic } \\
\text { kness }\end{array}$ & $\begin{array}{l}\text { 1st } \\
\text { shape } \\
\text { coeffi } \\
\text { cient }\end{array}$ & $\begin{array}{l}\text { 2nd } \\
\text { shape } \\
\text { coeffi } \\
\text { cient }\end{array}$ & $\begin{array}{l}\text { Lead } \\
\text { Core } \\
\text { Dia } \\
\text { mete } \\
\mathrm{r}\end{array}$ \\
\cline { 2 - 7 } & KN & $\mathrm{mm}$ & $\mathrm{mm}$ & $\mathrm{S} 1$ & $\mathrm{~S} 2$ & $\mathrm{~mm}$ \\
\hline $\begin{array}{l}\text { GZY } \\
400\end{array}$ & 1880 & 200 & 68.6 & 26.2 & 5.83 & 80 \\
\hline $\begin{array}{l}\text { GZY } \\
500\end{array}$ & 2940 & 250 & 96 & 26 & 5.21 & 100 \\
\hline $\begin{array}{l}\text { GZY } \\
600\end{array}$ & 4240 & 300 & 110 & 30 & 5.45 & 120 \\
\hline
\end{tabular}

\begin{tabular}{|c|c|c|c|c|c|}
\hline \multirow[t]{3}{*}{$\begin{array}{l}\text { model } \\
\text { numbe } \\
\mathrm{r}\end{array}$} & \multirow{2}{*}{$\begin{array}{l}\text { Vertic } \\
\text { al } \\
\text { Stiffn } \\
\text { ess }\end{array}$} & \multicolumn{2}{|c|}{$\begin{array}{l}\text { Horizontal } \\
\text { Deformation, } \\
50 \%\end{array}$} & \multicolumn{2}{|c|}{$\begin{array}{l}\text { Horizontal } \\
\text { Deformation, } \\
250 \%\end{array}$} \\
\hline & & $\begin{array}{l}\text { Equival } \\
\text { ent } \\
\text { Horizo } \\
\text { ntal } \\
\text { Stiffnes } \\
\text { s }\end{array}$ & $\begin{array}{l}\text { Equival } \\
\text { ent } \\
\text { Dampi } \\
\text { ng } \\
\text { Ratio }\end{array}$ & $\begin{array}{l}\text { Equival } \\
\text { ent } \\
\text { Horizo } \\
\text { ntal } \\
\text { Stiffnes } \\
\text { s }\end{array}$ & $\begin{array}{l}\text { Equival } \\
\text { ent } \\
\text { Dampi } \\
\text { ng } \\
\text { Ratio }\end{array}$ \\
\hline & $\begin{array}{l}\mathrm{KN} / \mathrm{m} \\
\mathrm{m}\end{array}$ & $\begin{array}{l}\mathrm{KN} / \mathrm{m} \\
\mathrm{m}\end{array}$ & - & $\begin{array}{l}\mathrm{KN} / \mathrm{m} \\
\mathrm{m}\end{array}$ & - \\
\hline $\begin{array}{l}\text { GZY } \\
400\end{array}$ & 1750 & 2.38 & 0.3 & 1.03 & 0.14 \\
\hline $\begin{array}{l}\text { GZY } \\
500\end{array}$ & 2030 & 2.65 & 0.3 & 1.15 & 0.14 \\
\hline $\begin{array}{l}\text { GZY } \\
600\end{array}$ & 2900 & 3.33 & 0.3 & 1.45 & 0.14 \\
\hline
\end{tabular}




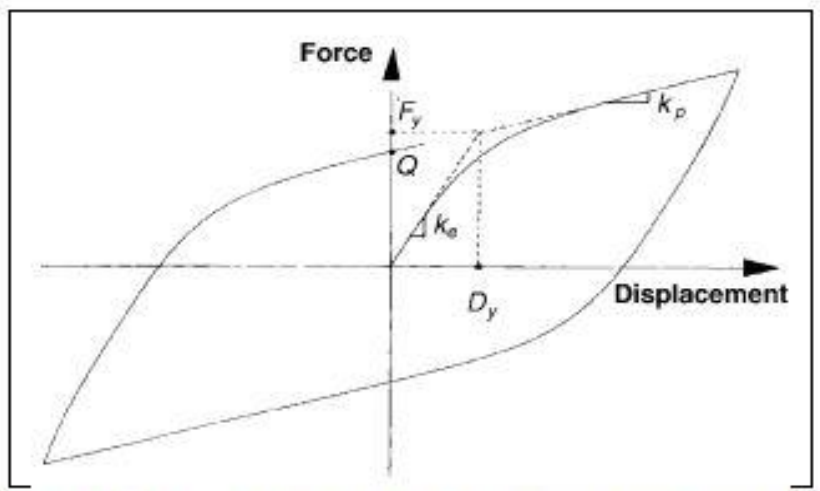

Figure C9-4 Idealized Hysteretic Force-Displacement Relation of Elastomeric Bearing

Fig -11: Idealized hysteretic behavior of LRB

\section{RESULTS AND DISCUSSION}

The masonry-reinforced concrete structural building is analyzed using the three ground motions and comparison is made with the response spectrum analysis as well. The non isolated maximum floor accelerations is shown in figure 12$\mathrm{a}$ and in figure $12 \mathrm{~b}$ is the enveloped time histories being compared to the response history analysis. Similar comparisons are done for the maximum floor velocities, shown in figures $13 \mathrm{a}, \mathrm{b}$ and also, the maximum floor displacements shown in figures $14 \mathrm{a}, \mathrm{b}$.

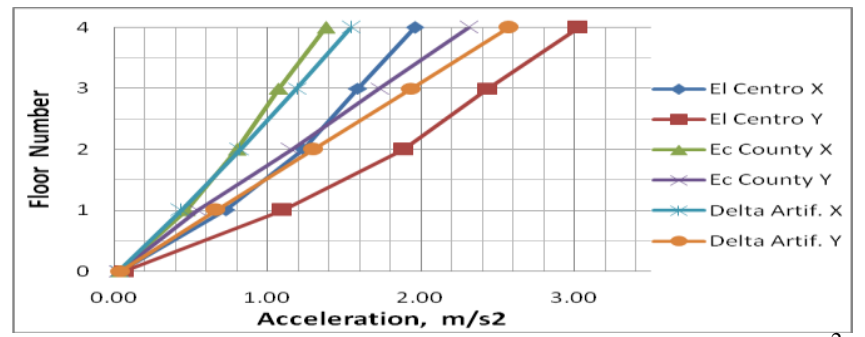

Fig -12a: Non-isolated maximum floor accelerations, $\mathrm{m} / \mathrm{s}^{2}$

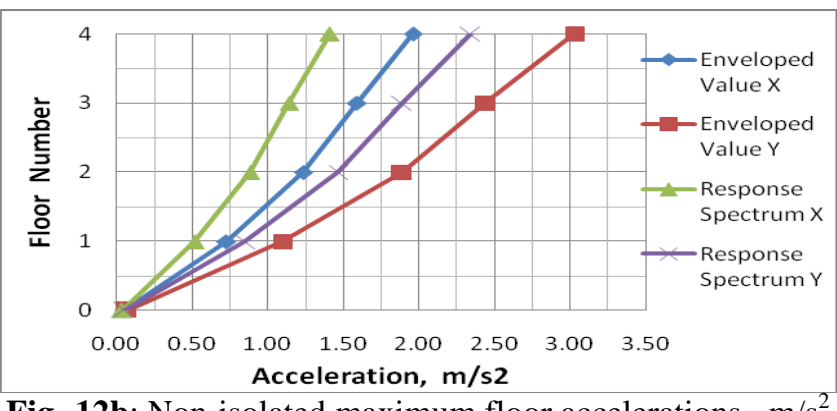

Fig -12b: Non-isolated maximum floor accelerations, $\mathrm{m} / \mathrm{s}^{2}$

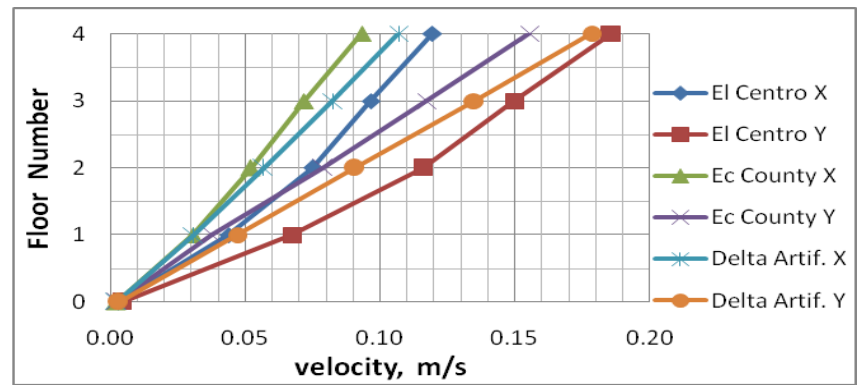

Fig -13a: Non-isolated maximum floor velocities, $\mathrm{m} / \mathrm{s}$

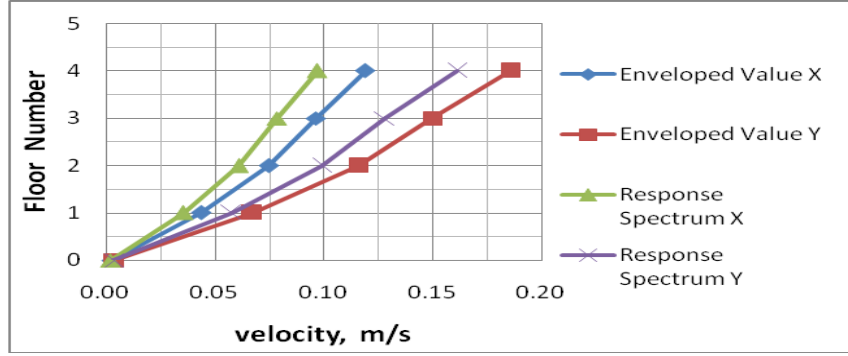

Fig -13b: Non-isolated maximum floor velocities, $\mathrm{m} / \mathrm{s}$

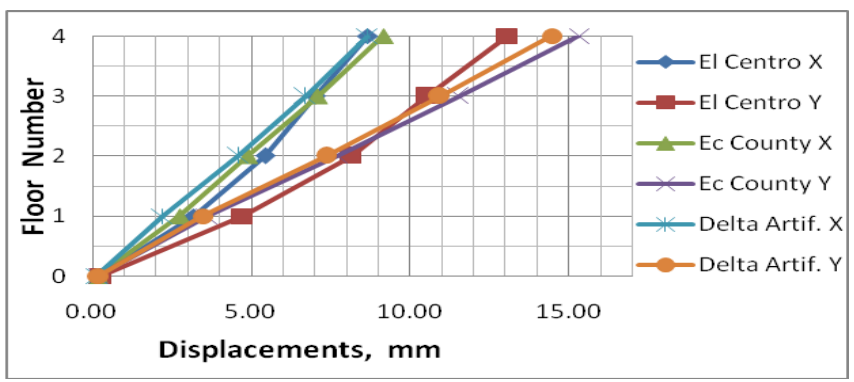

Fig -14a: Non-isolated maximum floor displacements, $\mathrm{mm}$

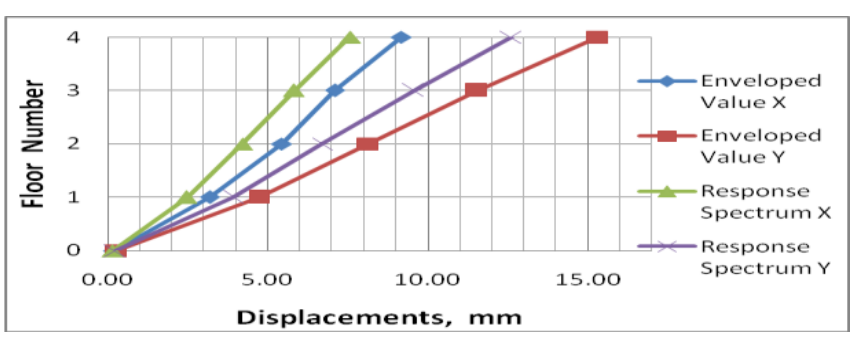

Fig -14b: Non-isolated maximum floor displacements, $\mathrm{mm}$

The ratio of displacements of each of the time histories against their corresponding response spectrums' are given in table 3 . In some projects, where maximum safety criteria are placed on the design of the structure, the response spectrum alone cannot be relied upon in analysis. As it can be seen in the case of this project, apart from Ec County Y-direction, and Delta Artif X, and Y-direction in both the 1st floor and the 1st floor base, the rest of the time histories, all have values greater than the response spectrum.

Table -3: Displacement Time History-Response spectrum ratios

\begin{tabular}{|l|l|l|l|l|l|l|}
\hline \multirow{2}{*}{$\begin{array}{l}\text { Wave } \\
\text { type }\end{array}$} & \multirow{2}{*}{$\mathrm{n}$} & \multicolumn{6}{|l|}{ Non Isolated Structure } \\
\cline { 3 - 7 } & & $\begin{array}{l}\text { 4th } \\
\text { floo } \\
\mathrm{r}\end{array}$ & $\begin{array}{l}\text { 3rd } \\
\text { floo } \\
\mathrm{r}\end{array}$ & $\begin{array}{l}\text { 2nd } \\
\text { floo } \\
\mathrm{r}\end{array}$ & $\begin{array}{l}\text { 1st } \\
\text { floo } \\
\mathrm{r}\end{array}$ & $\begin{array}{l}\text { 1st } \\
\text { floo } \\
\mathrm{r} \\
\text { base }\end{array}$ \\
\hline \multirow{2}{*}{ EL / RS } & $\mathrm{X}$ & 1.14 & 1.20 & 1.29 & 1.29 & 1.29 \\
\cline { 2 - 7 } & $\mathrm{Y}$ & 1.04 & 1.10 & 1.22 & 1.21 & 1.19 \\
\hline \multirow{2}{*}{ Ec / RS } & $\mathrm{X}$ & 1.21 & 1.22 & 1.16 & 1.12 & 1.14 \\
\cline { 2 - 7 } & $\mathrm{Y}$ & 1.21 & 1.21 & 1.15 & 0.93 & 0.70 \\
\hline \multirow{2}{*}{$\begin{array}{l}\text { DelArtif } \\
\text { / RS }\end{array}$} & $\mathrm{X}$ & 1.15 & 1.15 & 1.09 & 0.90 & 0.91 \\
\cline { 2 - 7 } & $\mathrm{Y}$ & 1.15 & 1.14 & 1.10 & 0.89 & 0.81 \\
\hline \multirow{2}{*}{$\begin{array}{l}\text { Env Val } \\
\text { / RS }\end{array}$} & $\mathrm{X}$ & 1.21 & 1.22 & 1.29 & 1.29 & 1.29 \\
\cline { 2 - 7 } & $\mathrm{Y}$ & 1.21 & 1.21 & 1.22 & 1.21 & 1.19 \\
\hline
\end{tabular}


The code demands that the maximum displacements for the topmost floor of the building be below the limited value, in this project scenario, $26.36 \mathrm{~mm}$. The values in the displacement graphs show that, they are indeed below $26.36 \mathrm{~mm}$. There is a further requirement to check whether the structure has entered into the elasto-plastic range, shown in table 4. This phenomenon is undesirable in our building structure and from the table, we observe that all the values are indeed greater than 0.01 .

Table -4: Inter-story displacements against code standard

\begin{tabular}{|c|c|c|c|c|c|c|}
\hline \multirow{2}{*}{$\begin{array}{l}\text { Wa } \\
\text { ve } \\
\text { typ } \\
\text { e }\end{array}$} & \multirow{2}{*}{$\begin{array}{l}\text { Dir } \\
\text { ec- } \\
\text { tio } \\
n\end{array}$} & \multicolumn{5}{|c|}{ Non Isolated Structure } \\
\hline & & $\begin{array}{l}\text { 4th } \\
\text { floor }\end{array}$ & $\begin{array}{l}\text { 3rd } \\
\text { floor }\end{array}$ & $\begin{array}{l}\text { 2nd } \\
\text { floor }\end{array}$ & $\begin{array}{l}\text { 1st } \\
\text { floor }\end{array}$ & $\begin{array}{l}\text { Cod } \\
\mathrm{e}\end{array}$ \\
\hline \multirow{2}{*}{$\begin{array}{l}\text { EL } \\
/ \\
\text { RS }\end{array}$} & $\mathrm{X}$ & 0.0025 & 0.0022 & 0.0016 & 0.0007 & \multirow{10}{*}{0.01} \\
\hline & $\mathrm{Y}$ & 0.0037 & 0.0033 & 0.0023 & 0.0011 & \\
\hline \multirow{2}{*}{$\begin{array}{l}\text { Ec } \\
/ \\
\text { RS } \\
\end{array}$} & $\mathrm{X}$ & 0.0026 & 0.0022 & 0.0014 & 0.0006 & \\
\hline & $\mathrm{Y}$ & 0.0044 & 0.0036 & 0.0022 & 0.0008 & \\
\hline \multirow{2}{*}{$\begin{array}{l}\text { Del } \\
\text { Art } \\
/ \\
\text { RS }\end{array}$} & $\mathrm{X}$ & 0.0025 & 0.0021 & 0.0013 & 0.0005 & \\
\hline & $\mathrm{Y}$ & 0.0041 & 0.0034 & 0.0021 & 0.0008 & \\
\hline \multirow{2}{*}{$\begin{array}{l}\text { En } \\
\text { V } \\
\text { Val } \\
\text { / } \\
\text { RS } \\
\end{array}$} & $\mathrm{X}$ & 0.0026 & 0.0022 & 0.0016 & 0.0007 & \\
\hline & $\mathrm{Y}$ & 0.0044 & 0.0036 & 0.0023 & 0.0011 & \\
\hline \multirow{2}{*}{$\begin{array}{l}\mathrm{Re} \\
\mathrm{sp} \\
\mathrm{Sp} \\
\mathrm{ec}\end{array}$} & $\mathrm{X}$ & 0.0022 & 0.0018 & 0.0012 & 0.0006 & \\
\hline & $\mathrm{Y}$ & 0.0036 & 0.0030 & 0.0019 & 0.0009 & \\
\hline
\end{tabular}

After the structure is isolated with the three types of base isolators, the maximum floor accelerations, velocities and displacements are shown in the figures $15 \mathrm{a}$ and $\mathrm{b} ; 16 \mathrm{a}$ and b; 17 a and b, respectively.

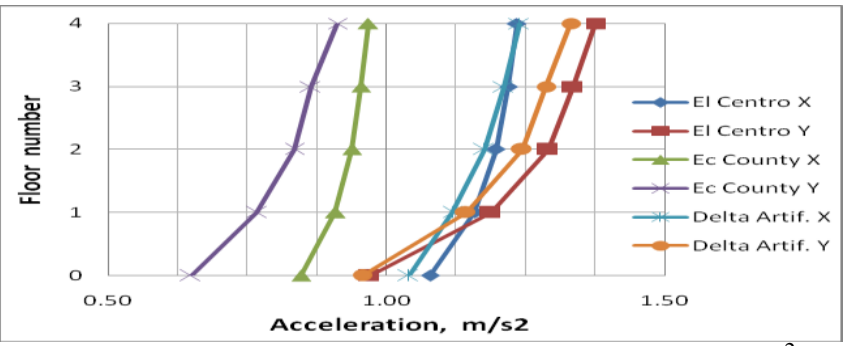

Fig -15a: Isolated maximum floor accelerations, $\mathrm{m} / \mathrm{s}^{2}$

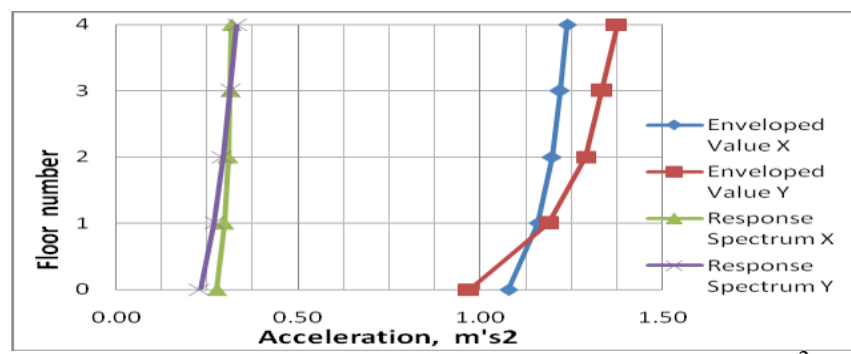

Fig -15b: Isolated maximum floor accelerations, $\mathrm{m} / \mathrm{s}^{2}$

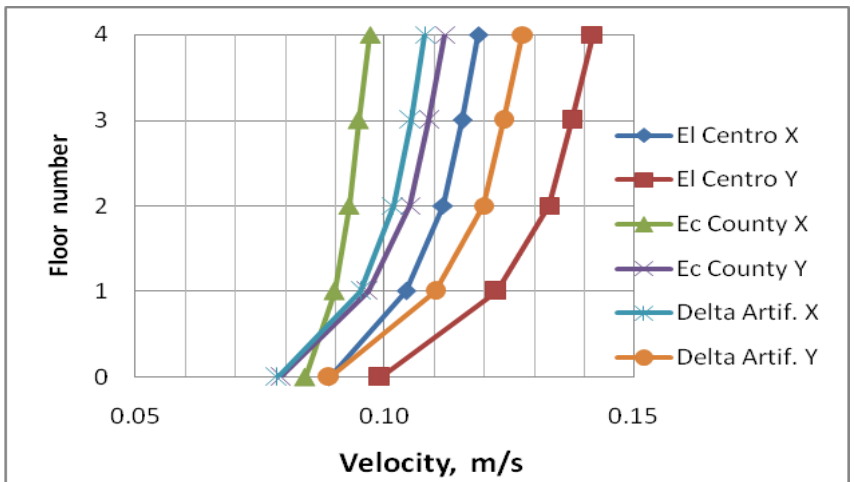

Fig -16a: Isolated maximum floor velocities, $\mathrm{m} / \mathrm{s}$

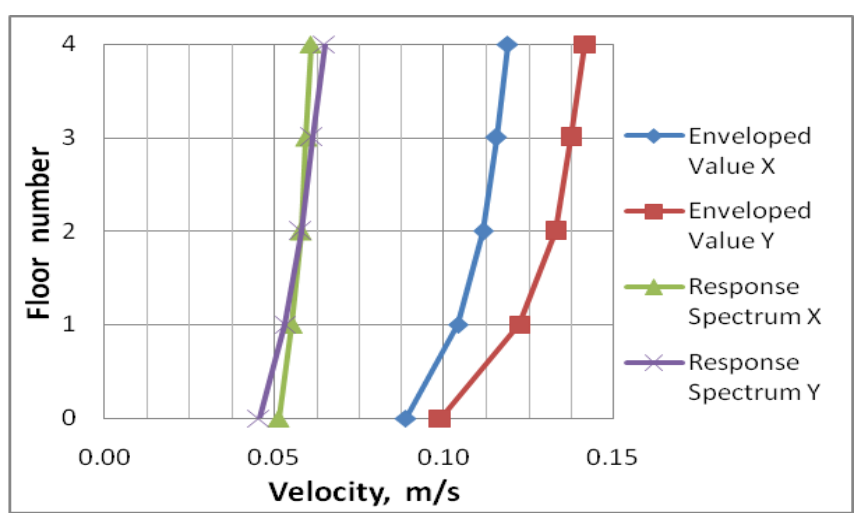

Fig -16b: Isolated maximum floor velocities, $\mathrm{m} / \mathrm{s}$

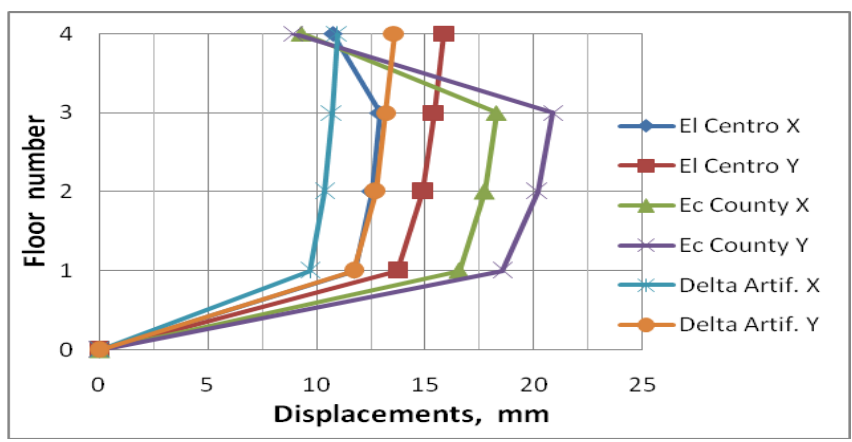

Fig -17a: Isolated maximum floor displacements, $\mathrm{mm}$

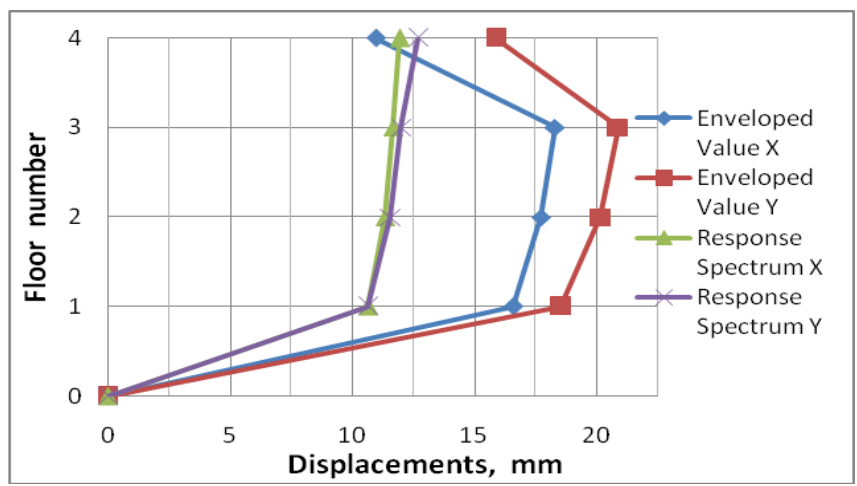

Fig -17b: Isolated maximum floor displacements, mm

The isolated model is shown in figure 18, displaying the movement of the entire building as an entity. The shaded region shows the original position of the building. All together, the number of isolators used in this project are 31 of LRB 400, 19 of LRB 500 and 3 of LRB 600. 


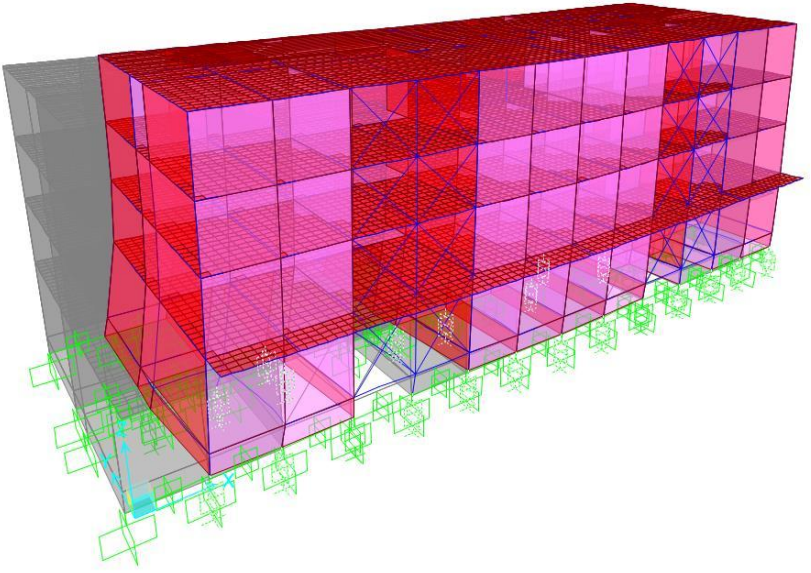

Fig -18: Isolated building model

The isolated structure is seen to have reduced in acceleration, reduced in velocity and increased in displacement. Table 5 gives the ratio of isolated building accelerations to non isolated building accelerations.

Table -5: Ratio of isolated to non isolated accelerations

\begin{tabular}{|c|c|c|c|c|c|}
\hline \multirow[t]{2}{*}{ Wave type } & \multirow{2}{*}{ 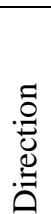 } & \multicolumn{4}{|c|}{$\begin{array}{l}\text { Ratio of isolated Acceleration to } \\
\text { non isolated Acceleration }\end{array}$} \\
\hline & & $\begin{array}{l}\text { 4th } \\
\text { floor }\end{array}$ & $\begin{array}{l}\text { 3rd } \\
\text { floor }\end{array}$ & $\begin{array}{l}\text { 2nd } \\
\text { floor }\end{array}$ & $\begin{array}{l}1 \mathrm{st} \\
\text { floor }\end{array}$ \\
\hline \multirow[t]{2}{*}{ El Centro } & $X$ & 0.63 & 0.77 & 0.97 & 1.60 \\
\hline & $\mathrm{Y}$ & 0.45 & 0.55 & 0.68 & 1.08 \\
\hline \multirow[t]{2}{*}{ Ec County } & $\mathrm{X}$ & 0.70 & 0.89 & 1.17 & 1.93 \\
\hline & $\mathrm{Y}$ & 0.39 & 0.50 & 0.72 & 1.41 \\
\hline \multirow[t]{2}{*}{ Delta Artif } & $\mathrm{X}$ & 0.80 & 1.01 & 1.43 & 2.56 \\
\hline & $\mathrm{Y}$ & 0.52 & 0.66 & 0.96 & 1.72 \\
\hline \multirow{2}{*}{$\begin{array}{c}\text { Enveloped } \\
\text { Value }\end{array}$} & $\mathrm{X}$ & 0.80 & 1.01 & 1.43 & 2.56 \\
\hline & $\mathrm{Y}$ & 0.52 & 0.66 & 0.96 & 1.72 \\
\hline \multirow{2}{*}{$\begin{array}{l}\text { Response } \\
\text { Spectrum }\end{array}$} & $\mathrm{X}$ & 0.23 & 0.27 & 0.35 & 0.58 \\
\hline & $\mathrm{Y}$ & 0.14 & 0.17 & 0.20 & 0.32 \\
\hline
\end{tabular}

Table 6 shows the percentages of accelerations reduced, percentages of velocities reduced and the percentages of displacements increased for the $4^{\text {th }}$ floor of the building structure.
Table -6: Percentages (\%) increased or decreased on the 4th floor

\begin{tabular}{|c|c|c|c|c|}
\hline Wave type & Direction & Accel. & Vel. & Displ. \\
\hline \multirow{2}{*}{ El Centro } & $\mathrm{X}$ & 37.11 & 0.42 & 23.81 \\
\cline { 2 - 5 } & $\mathrm{Y}$ & 54.59 & 23.68 & 21.38 \\
\hline Ec County & $\mathrm{X}$ & 29.98 & -4.30 & 1.55 \\
\cline { 2 - 5 } & $\mathrm{Y}$ & 60.57 & 27.82 & -41.84 \\
\hline \multirow{2}{*}{\begin{tabular}{c} 
Delta Artif \\
\cline { 2 - 5 }
\end{tabular}} & $\mathrm{X}$ & 19.69 & -1.03 & 26.36 \\
\hline \multirow{2}{*}{$\begin{array}{c}\text { Enveloped } \\
\text { Value }\end{array}$} & $\mathrm{Y}$ & 48.33 & 28.42 & -6.23 \\
\cline { 2 - 5 } & $\mathrm{Y}$ & 60.57 & 28.42 & 21.38 \\
\hline $\begin{array}{c}\text { Response } \\
\text { Spectrum }\end{array}$ & $\mathrm{X}$ & 77.50 & 37.45 & 57.59 \\
\cline { 2 - 5 } & $\mathrm{Y}$ & 85.82 & 59.76 & 0.62 \\
\hline
\end{tabular}

It is seen that, all the accelerations reduced significantly, whereas considering the values of velocities, apart from two of their components, the remainder all experienced reduction. Two of the displacement components also did not increase, with the exception of those, the rest of the components experienced increments. It can be inferred that, the strength of the isolators used should be increased, thus, the 31 LRB 400s should be reduced and the LRB 500s and LRB 600s increased to reflect a significant difference in the results. The maximum percentage decrease in acceleration and velocity can be seen occurring in the response spectrum, namely, $85.82 \%$ and $59.76 \%$ respectively. The maximum percentage increase in the displacement is also evident in the response spectrum, $57.59 \%$. In the time histories, the maximum is seen in Ec County Y-direction for the acceleration reduction at a value of $60.57 \%$; Delta artif records a maximum velocity reduction of $28.42 \%$ in the $\mathrm{Y}$ direction and finally, the Delta artif X-direction records a maximum displacement increment, at a value of $26.36 \%$.

\section{CONCLUSIONS}

Following the directives outlined in the Chinese code for the seismic design of buildings and strengthening of a masonryreinforced concrete structure by placing seismic isolators, it is inferred that the floor joint accelerations and floor joint velocities were reduced and the floor joint displacements increased.

The response spectrum should not be used alone as the ground excitation for the structure or as a measure of introducing ground accelerating vibrations into a seismic design of structures but also the time histories should be included, choosing them according to the site and building classifications.

The use of the base isolators should be selected with a higher model strength parameter isolator in mind, especially if a significant difference is expected in the output of the structural response to the earthquake excitation. 


\section{REFERENCES}

[1]. Zhou Ying, Lu Xilin, Revelations on the Seismic Damage of High-rise Reinforced Concrete Structures from the Chile Earthquake (in Chinese), Journal of Building Structures, vol. 1000-6869, 2011, 05-001707

[2]. Ying Zhou, Xilin Lu, Jiang Qian, Dynamic Test on a Multi-Tower Connected Building Structure, National Natural Science Foundation of China (Grant No. 50708071, 90815029)

[3]. Qin Li, Trend of high rise building design - industrial cluster and urbanization of high rise buildings (in Chinese), http://www.cnki.net

[4]. GB50010-2010, Code for Design of Concrete Structures (in Chinese), Peoples Republic of China

[5]. GB 50011-2010, Code for Seismic Design of Buildings (in Chinese), Peoples Republic of China

[6]. PAN Peng, YE LiePing, SHI Wei, CAO HaiYun, Engineering practice of seismic isolation and energy dissipation structures in China, Science ChinaTechnological Sciences, vol. 55, No. 11: 3036-3046, Nov. 2012, doi:10.1007/s11431-012-4922-6

[7]. Constantine Shuhaibar, Examples for Seismically Isolated Buildings and Buildings with Supplemental Damping, Structural Engineers Association of California, Webinar:2012 IBC SSDM - Volume 5, February 13, 2014

[8]. Vasant A Matsagar, R. S. Jangid, Base isolation for seismic retrofitting of structures, Practice Periodical on Structural Design and Construction, ASCE, November 2008-175-185

[9]. Zhang Hui, Zhao Ling-yun, Liu Xiao-feng, Analysis on active characteristics of small earthquakes at Huating in Pingliang area (in Chinese), Earthquake Research in Plateau, Vol. 18 No. 4, Dec. 2006

[10]. PKPM 2010, v2.2, Peoples Republic of China

[11]. Sap2000 Ultimate 17.1.1, Build 1099, Computers and Structures Inc., Copyright (C) 1976-2014

[12]. Pacific Earthquake Engineering Research Center (PEER), NGA-West2 on-line ground-motion database tool, Peer ground motion database, Berkeley, USA

[13]. Seismosoft Products, SeismoArtif v2.1.2, SeismoSignal v5.0.0, 27100 Pavia, Italy

[14]. GB 20688.3-2006, Code for Rubber bearings- Part 3: Elastomeric seismic-protection for buildings, (in Chinese), Peoples Republic of China

[15]. Isolator bearing properties Guangdong Yutai Isolation Technology Limited Company, China P.R.

[16]. FEMA 274, Federal Emergency Management Agency, Nehrp Commentary on the guidelines for the seismic rehabilitation of buildings, October 1997

\section{BIOGRAPHIES}

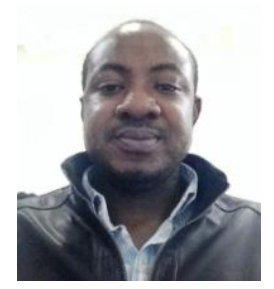

Okine Michael is a Civil Engineering student of Lanzhou Jiaotong University in Lanzhou city, pursuing a Masters Degree in Structural Engineering. His research areas include seismic design, seismic base isolation and flue gas desulphurization chamber design.

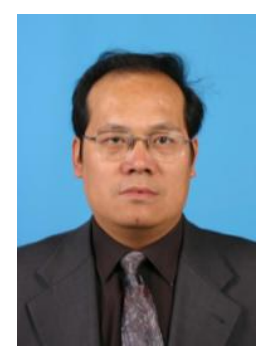

Professor Zhao Jianchang is a full professor, lecturing in Lanzhou Jiaotong University. He is a famous Structural Engineer in the Gansu province, having served on many committees. His research areas include Structural Engineering, Bridge Engineering, prestressed concrete, strengthening of structures, flue gas desulphurization chamber design, etc.

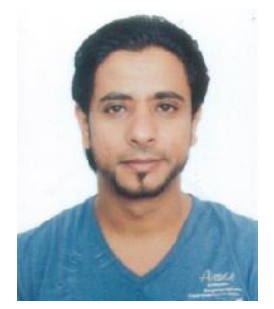

Mashrah Waleed is a Civil Engineering student of Lanzhou Jiaotong University in Lanzhou city, pursuing a Masters Degree in Structural Engineering. His research areas include seismic design, high-rise building design. 